\title{
EDEBİ METINNLERDE AĞIZ KULLANIMI: BEKİR YILDIZ ÖRNEĞİ
}

\author{
THE DIALECT USE IN LITERARY WORKS: THE CASE OF BEKIR \\ YILDIZ
}

Gülbeyaz GÖZTAŞ*

\begin{abstract}
$\ddot{O} z$
A ̆̆gzlar, fonolojik, morfolojik, sentax, söz varlı̆̆ açısından çeşitli farklarla standart dilden ayrılan konuşma biçimleridir. Standart dil ile yazılan eserlerde çeşitli sebeplerle ă̆ızlara yer verildiğ $i$ görülmektedir. Metinlerde ă̆ız kullanımı, Toplumcu-Gerçekçi yazarlar tarafindan tercih edilmiştir. Ağızlar, işlenen olayın gerçekçiliğini ve okur karşısındaki etkisini arttırması, toplumla arasındaki bağı göstermesi amacıyla metinlerde kullanılmıştır. Bu çalışmada, Bekir Yıldız'ın hikâyelerinde kullandi $\breve{g} \imath$ ă̆ızlar incelenmiştir. Metinler, standart dille yazılmış, diyaloglarda ve iç monologlarda ă̆ız kullanılmıştır. Fişlenen malzeme fonoloji, morfoloji, sentax ve söz varlı̆̆ı başlıkları altında incelenmiştir. Kullanılan ağız, Leyla Karahan'ın sınıflandırmasına göre Doğu Grubu Ağızıdır. Yazarın doğuda geçen hikâyelerinde ă̆ızlara rastlanmış, fakat kent yaşamında, özellikle Almanya yolcusu olan kahramanların dilinde rastlanmamıştır. Metinlerde fonolojik ve morfolojik açıdan bölgeye özgü tipik ă̆ız özelliği barındıran malzemenin yanı sıra, söz varlı̆̆ı açısından ilgi çekici, yöreye özgü yerel sözcükler, deyim ve atasözleri, dualar, beddualar, yemin ifade eden kaliplar, ünlemler, argo sözler yer almaktadır. Derleme Sözlü̆̆̈̈, Bölge A ̆̆ılarında Atasözleri ve Deyimler Sözlüğ̈̈̈nden yararlanılarak verilerin Doğu Grubu Ağılarının konuşulduğu bölgelerde yaygın biçimde kullanıldı̆̆ı tespit edilmiştir. Edebi metinlerde ă̆ız kullanımı, ă̆ız derlemelerine ait bir doküman olarak incelenebilir. Bu tip çalışmalar Derleme sözlü̆̆̈̈ne katkı sağlayacaktır. Almanya'da geçen hikâyelerde bulunmayan ağız ve değişen söz varlı̆̆ı toplumsal yapı ve dildeki değişmeleri göstermektedir.
\end{abstract}

Anahtar Kelimeler

Edebi metin, hikâye, ă̆ız, Bekir Yıldız.

\begin{abstract}
Dialects are different from the standard language in terms of morphology, syntax and vocabulary. Literary works, written with the standard language, can also contain dialects for various reasons. Socialist-Realist writers prefer to use dialects in their literary works. Dialects are employed in literary works to increase the reality of the subject matter, to boost the subject matter's impact on the reader. In this study, the dialect used in Bekir Yildiz's stories is analyzed. Texts, written with the standard language, contain dialects within dialogues and interior monologues. The specified data are analyzed under the subtitles of phonology, morphology, syntax and vocabulary. The dialect can be characterized as "East Group Dialect" according to Leyla Karahan's classification. Dialects are used
\end{abstract}

Arş. Gör., Artvin Çoruh Üniversitesi, İstanbul Üniversitesi, Yeni Türk Dili Ana Bilim Dalı Doktora Öğrencisi, gulbeyazgoztas@artvin.edu.tr 
in Yildiz's stories that are taking place in the East, yet they are not used in the city life and especially in the language of the characters going to Germany. In the texts, in addition to material features typical of the region in terms of phonological and morphological aspects, there are local words, idioms and proverbs, prayers, impracation phrases of attestation, expressions of swearing, exclamations and slangs which are interesting in terms of vocabulary. Dialect used in literary works can be examined as a document of dialect compilations. The fact that dialect is not employed in the stories taking place in Germany shows the changes in the social structure and language.

\section{Keywords}

Literary texts, story, dialect, Bekir Yuldiz. 


\section{Giris}

Bireylerin oluşturduğu toplumda farklı toplumsal yapı ve katmanlar ortaya çıkar. Bu topluluklar benliklerinin izlerini taşıyan, onları var eden dillerle anlaşır. İktisadi, sosyal, kültürel, etnik açıdan çeşitlilik gösteren bu insanlar sayesinde dil de çeşitlenir ve değişir. Dilin, toplumsal katmanlar ve yapı içinde farklılaşmadan, eğilip bükülmeden, genişlemeden, daralmadan tek bir çizgi halinde konuşulması imkânsızdır. Tüm değişmeleri toplumunun yaşadıklarına denk tutmak ve bunları göz önünde bulundurarak incelemek gerekir (İmer 1990: 15). Toplum hayatındaki her türlü kültürel, sosyal değişme, dili doğrudan etkilemekte ve dilin iç gelişmesi ile birbirine paralel olarak yürümektedir. Sürekli bu değişime maruz kalan toplumun yazılı olarak sağlıklı bir iletişim kurması için ortak anlaşmayı sağlayacak gündelik değişmelerden fazlaca etkilenmeyen ölçünlü bir dile ihtiyacı vardır. Yazı dili söz konusu ölçünlülüğü gramer kuralları ve sözlüksel özellikleri sayesinde koruyarak iletişimi temin eder (Akar 2009a: 2). Bireylerin anlaşabilmesi için dilleri içinde belirli bir konuşma varyasyonunu anlaşma dili olarak seçmeleri, kodlamaları, işlevlerini geliştirmeleri ve bu dili resmi anlaşama dili olarak kabul etmeleri gerekir (Demirci 2014: 250). Bu seçilmiş dil "standart dil" olarak adlandırılır (İmer 1990: 15). Bir bölgenin ağzına dayanan, kendisi de neticede bir ağız olan, bölgeler ve sosyal tabakalar üstü konuma sahip standart dil; ulaşım, iletişim, eğitim, edebiyat, siyaset ve tüm resmi işlemlerde kullanılması gereken ortak varyasyondur (Demir 2009: 3). Bir toplumun büyüyüp çoğalması, boylara, aşiretlere ayrılması, farklı coğrafyalarda yurt tutması, farklı etkilere maruz kalmasına neden olur ve ayrışmalar başlar. Bu farklılaşma önce toplumun kavram dünyasında sonra da dilinde değişikliklere sebep olur. Böylece dilde çeşitli varyasyonlar ortaya çıkar (Buran 2002: 97). Alt katmanın konuşma dili, "ağız" olarak adlandırılan bu varyasyonlar sayesinde oluşur. Ağız: "Bir dilin veya lehçenin yazı diline oranla ve çoğunlukla ses, bazen de şekil, anlam ve söz varlığı bakımından birbirinden az çok ayrılan konuşma biçimleri" olarak tanımlanır (Korkmaz 2010: 12). Türkiye Türkçesi İstanbul ağzına dayalı bir yazı diline sahiptir. Leyla Karahan Türkiye Türkçesi ağızlarında Batı Grubu, Doğu Grubu, Kuzey-doğu Grubu olmak üzere üç ana ağız grubu belirlemekte, ana ağız gruplarını belirli sinıflandırmalara göre alt gruplara ayırarak daha sistemli bir sinıflandırma yapmaktadır (Karahan 2011: 2). Bu sınıflandırmaya Rumeli ağızlarını da dâhil etmek gerekir.

\subsection{Standart Dil ve Ağız İlişkisi}

İletişimin sağlanabilmesi için kelimelerin mesaj veren ile alan arasında doğru biçimde anlaşılması gerekir. Bunun yazı dili bağlamında gerçekleşmesi genellikle sözlükteki anlamıyla mümkün olur. Göstergenin sözlük anlamı, modern dil biliminde genel ve ikincil anlamdır. Asıl anlam, konuşma anında oluşan bağlam ile ortaya çıkar. Sözlü dilde, konuşma anında oluşan anlam, yazı dilinde metnin okunmasıyla meydana gelir. Yazı dilinde mesaj yazı ile ulaştııılmaktadır. Böylece söz değeri yerine dil göstergesi belli kavramı yahut kavramları ifade etmektedir. Verilmek istenen mesaj yazı dili içinde kullanılması mümkün olan sözcükler tercih edilerek aktarılır. Bilgi aktarımının gerçekleşmesi için sözcükler sözlüklerdeki anlamları esas alınarak seçilir. Bu da yazı dilini sözlü dilden daha sınırlandırılmış yapar. Oysaki dilimizde çoğu sözcüğün anlamı tek olmamakla birlikte sözlü iletişim sırasında yeni anlamlar kazanmaktadır (Akar 2009a: 2-3).

Tarihî yazı dillerinin birçoğu standart değildir ve bu dillerle yazılmış edebî metinlerde 
sözlü dil özelliklerini fazlasıyla görmek mümkündür. Yazı dilinin standartlaşması, devlet bürokrasisinin kurumsallaşmasından sonraki dönemlere denk düşer. Yazı dili, önce bir devlet dili, hukuk dili olarak doğar; daha sonra eğitim, bilim ve edebiyat alanlarında kendini gösterir. Resmî yazının hukukî değeri, yazı ölçünlülüğünü önemli kılar ve dil standartlaşır (Akar, 2009a: 5). Yazı dili ölçünlü olması ve anlaşmayı sağlayıcı genel-geçer bir iletişim aracı olması sebebi ile kullanım standartları belirlenmiş bir dildir. Bununla birlikte ağızları ve standart dili kesin sınırlarla birbirinden ayıracak bir dil bilimi ölçütü yoktur. Fakat standart dil ile ağızlar arasındaki en önemli fark, standart dilin öncelikle yazılı, ağızların ise sözlü kullanılmasıdır. Standart varyant, dil türleri arasında en geniş işlev ve geçerlilik alanına sahiptir. Ayrıca teorik ve kuralcı dil incelemelerinde temel alınan biçimdir (Demir 2013: 17). Standart dil, sahip olduğu araçlarla yerel ağızları bir taraftan kendine yaklaştırmakta, ağız bölgelerine yayılmakta ve yerel ağızların birincil özelliklerinin kaybına neden olmaktadır. Diğer taraftan kendisi de ağızlardan beslenmektedir. Ağızlar ise bir taraftan standart dile yaklaşırken diğer taraftan standart dile ait olduğu düşünülen bazı alanlarda kendilerine yer bulmaktadır. Ağızlar; eğitim ve resmi işler hariç, standart dille aynı araçları kullanarak, iç göçün de yardımıyla asıl konuşuldukları bölgelerin dışına taşmaktadır (Demir 2010: 96; 2013: 17). Dildeki gelişme, değişme ve yeni kavram alanı oluşumu, ağızlarda yazı diline göre daha hızlı gerçekleşir. Yazı dili, durgun ve kolay kolay değişmez bir yapıya sahipken, ağızlar değişken ve canlıdır. Yazı dili, ağızların bu canlı söz varlıklarından beslenerek zenginleşir. Dil devrimi sırasında yapılan derlemelerin, yazı diline büyük katkısı vardır. Bu sözlerin bir bölümü bugün yazı dilimizde yaygın olarak kullanılmaktadır (Akar 2009b: 217). Ağızlar ortak dilden aldıkları malzeme ile kelime hazinesini zenginleştirmekte ve cümle kuruluşunu çeşitlendirmektedir. Standart dil ise kelime ve eklerin işlevleri konusunda ağızlardan yararlanmaktadır. Fakat ağızlar standart dile çok fazla maruz kalırsa standart dil içinde eriyip kaybolabilir (Buran 2002: 98). Ortak bir yaşama alanını paylaşan kişilerce kullanılan ağız, insanlar arasındaki iletişimi kolaylaştırır ve aidiyet duygusunu perçinler. Birey ağız kullanırken kendisi olmakta ve ait olduğu toplumsal etnisiteyi temsil etmektedir. Toplumda ağız kullanımı kişiler arasındaki samimiyete ve yakınlığa bağlıdır. Bu sebeple ağızlar toplumsal yapı içinde bağlayıcı bir işleve sahiptir. Fakat eğitimin, medyanın ve resmi kurumların kullandığı dilin standart dil olması ağızların hâkim olduğu alanı daraltmaktadır. Standart dil yaygınlaştıkça ağızlar üzerindeki tek tipleştirici etkisinin arttığ görülmektedir. Teknolojinin gelişmesine paralel olarak dizilerde, filmlerde, sosyal medyada, bazı yerel internet sitelerinde ağız kullanımı yaygınlaşmaktadır (Demir 2013: 24-25). İç ve dış göçler de bireyin ağız ve standart dil kullanımını etkiler (Aydın 2011: 1898; Demir 2013: 26). Bunların dışında yazılı metinlerde yani standart dil içerisinde de ağız kullanıldığı görülür.

\subsection{Edebi Metinlerde Ağız Kullanımı}

Yazı dilindeki tek biçimlilik daha çok standart yazımla ilgilidir. Yazı dilinin kullanıldığı bazı alanlar ağız kullanımına tamamıyla kapalıyken bazıları açıktır. Geniş kesimlerce kolay anlaşılması beklenen ders kitaplarında ve resmi işlevi olan metinlerde ağız kullanılmamaktadır (Demir 2013: 21). Masal, halk hikâyesi, efsane, atasözü, deyim, bilmece, fikra, halk şiiri, türkü gibi sözlü edebiyat ürünlerinin yazıya geçirilmiş biçimlerinde, karikatürlerde, tiyatro metinlerinde, öykü ve romanların öncelikle diyalog bölümlerinde ve yerel basında ağız kullanılır (Demir 2009: 2). Ağız ve edebiyat arasında iki türlü edebi ilişkiden bahsedilebilir. İlk olarak bir ağzın temel anlatım dilini oluşturduğu metinler anlamında ağız edebiyatı, ikincisi ise standart dille yazılmış bir edebi metinde, çeşitli nedenlerle ağız örneklerine yer verilmesi anlamında, edebi metinlerde ağız varlığından söz edilebilir (Demir 2009: 3). Eldeki çalışma ikinci tür metinlerden hareketle oluşturulmuş bir çalışmadır. Genellikle toplumcu-gerçekçi 
yazarların metinlerinde ağızlardan çok sık yararlandığı görülmektedir. Bu akıma göre sanatın yansıttığ gerçeklik, toplumsal gerçekliktir. Köylüyü ya da köyü yazmak için onlar gibi yaşamayı, düşünmeyi, konuşmayı benimserler (Masdar 2012: 2390). Bu açıdan yazarlar eserlerinin çoğunda köydeki yaşamı anlatmakta, köydeki bireyin dilini kullanmaktadır. Her bireyin ait olduğu toplumun coğrafi ve kültürel özellikleri, dil kullanımda kendini gösterir. Kültürel bir zenginlik ifadesi olan ağız, uygun yer ve koşullarda kullanıldığında bireyin aitlik ve güven duygusunu besler (Şengül 2009: 2173). Bu bağlamda toplumcu-gerçekçi yazarlar, kahramanlarına ağız kullandırmak suretiyle anlattıkları hikâyenin gerçek bir topluma ait olduğunu göstererek okuyucunun güvenini kazanmak ve hikâyenin gerçekliğini göz önüne sermek için ağız kullanmaktadır. Edebiyatta ağız kullanımı daha çok 1950'li yıllarda ortaya çıkar. Halkın yaşadıkları, yine halkın gözünden ve dilinden anlatılır ve daha etkili bir anlatım sağlanması amaçlanır. Fakat bu üslubu kullanan yazarlar çokça eleştirilirler. Hikâyelerde, kişilerin ağızlarıyla konuşturulması dönem içinde en çok eleştirilen ve tartışılan üslûp konusu olur. 1954 yılında özellikle toplumcu-gerçekçi yazarların eserlerinde ağız kullanmaları daha çok edebiyatta köy konusunun işlenmesiyle ele alınır. Bu moda Orhan Kemal'in eserlerinde ağız kullanması ile başlamakta, daha sonra Mehmet Fuat'ın açıklamaları "köylü konuşmasının" hızla eserlerde yayılmasını sağlamaktadır. Bazı eleştirmenler sanatçıların aydınlar ve belirli bir zümre için yazdığını, eserlerde köylü konuşmasının kabul edilemeyeceğini, hatta bu üslubun uydurulmuş ekler ve kelimelerden mütevellit bir dil olduğunu belirtirler. Kimi eleştirmenler ise hikâye ve romanın konusu köylü konuşmasına yer verilmesini gerektiriyorsa yazarın yeri geldiğinde bu dili kullanması gerektiğini savunur. Ayrıca döneminde bu üslup argo olarak nitelendirilmektedir (Baycanlar 2007: 161,242). Orhan Kemal, Yaşar Kemal, Kemal Bilbaşar, Samim Kocagöz gibi yazarlar ağız kullanımına taraf olurlar. Ahmet Buran, çağdaş edebî metinlerde yer alan mahallî kelimelerin tespiti üzerine bir çalışma yaparak Yaşar Kemal, Kemal Tahir, Ömer Polat, Mustafa Necati Sepetçioğlu, Tarık Buğra, Talip Apaydın, M. Akif Ersoy, Reşat Enis Aygen, Mustafa Kutlu, Kemal Bilbaşar, Abdürrahim Karakoç gibi çeşitli yazarların eserlerinde çok sayıda mahallî kelime tespit eder (Buran 2002: 103). Ali Püsküllüoğlu da Yaşar Kemal'in eserlerinde geçen yerel sözcüklere, atasözlerine ve deyimlere yer veren bir sözlük yayımlar (Demir 2009: 5). Yukarıda isimlerini zikrettiğimiz yazarlarımızın metinlerinde halkın diline rastlamak mümkündür. Eserlerinde ağızı bolca kullanan, toplumcu-gerçekçi olarak adlandırılan Bekir Yıldız'ı da bu yazarlar arasında zikretmek gerekir. Metinlerde genellikle diyaloglarda ve iç monologlarda ağız kullanıldığı görülmektedir. Yazar anlattığı öykünün daha gerçekçi olması, vermek istediği mesajın okurda etkisinin artması, kahramanların yapay olmaması için metinlerde ağız kullanmaktadır. Yerel dil kullanarak yermek istenen olayları, kişileri halkın dili ile daha ironik ve gerçekçi olarak anlatırlar. Bu yazarlar eserlerine atfettikleri misyonu yerine getirmek için ağızı araç olarak kullanır. Standart dille söyleyemeyecekleri argo sözleri, küfürleri, bedduaları ağızla verirler. Bununla birlikte metnin akıcı, anlaşılır ve sade bir üslupla yazılması sağlanır. Ağızların metnin diline ve vermek istediği mesaja sağlamış olduğu katkının yanında bir metinde ağzın tercih edilmesinin ağız araştırmalarına katkı sağladığ muhakkaktır. Öncelikle ait olduğu toplumun kültürünü, dilini yansıtması bakımından önemlidir. Metinde geçen yerel varyanta ait söz varlığı tarama ve derleme sözlüğü açısından kıymetlidir. Bu metinler ağız metinleri olarak incelenebilir ve ses, şekil, söz varlığı ve söz dizimi açısından sınıflandırılması yapılarak ait olduğu bölgedeki ağız özellikleri ortaya çıkarılabilir. Böylelikle veriler, uzman kişilerce yapılmış bir derleme niteliği kazanabilir. Çünkü çoğunlukla yazarlar ya bu bölgenin insanı ya da bölgenin diline hâkim kişiler olmaktadır. Yazar hem ortak dili hem yerel varyantı ustalıkla kullanabilmektedir. Alt katman dili olan ağızlar genellikle 
ortak dilden bilgi, moda ve özenti alıntıları yapmakta, üst katman dili olan ortak dil ise ağızlardan, daha çok bilgi alıntıları yapmaktadır. Yeni bir olguyu adlandırmada ya da yabancı bir sözcüğe Türkçe bir tanımlama yapılması gerektiğinde yerel varyanta yani halkın diline de başvurulmaktadır (Zülfikar 2011: 175). Böylelikle ağızlardan alınan kelimeler yazı dilinin kavram dünyasını geliştirmekte ve zenginleştirmektedir. Ortak dilin ağızlardan yararlanmaya devam etmesi için bu yolun açık tutulması ve bu yolla yazı diline geçen kelimelerin de tespit edilerek ortak dilin sözlüklerine eklenmesi gerekmektedir (Buran 2002: 103). Yazılı metinlerde ağız kullanımı konuşma diline ait kelimelerin yazı diline geçişini sağlamaktadır. Ancak her yazılı metinde kullanılan kelime ortak dile girmiş sayılamaz. Ağızlardan alınan kelimeler bilim alanları için terim olabilmekte ve ortak dili kullanan çeşitli yazarların yazılarında yer alabilmektedir. Bu durum, yazı diline ait olabilmenin ilk aşaması sayılabilir ve bundan sonraki aşama ise bu kelimelerin yaygınlaşması ve standart dil içerisinde kabul görmesidir (Buran 2002: 102-103). Böylelikle yazılı metinlerde ağız kullanımı standart dilin söz varlığını hem sayısal olarak hem anlamsal olarak zenginleştirmektedir. Aynı zamanda yazılı metinler ağızlar için bir derleme nüshası özelliği taşımaktadır. İletişim karmaşasını önlemek amacıyla yazı dili sözlüğü, kelimeye yüklenebilecek sonsuz sayıdaki anlam çeşitliliğini sınırlar. Fakat canlı dil verilerine dayanan ağız sözlüğü, ölçünlü dile göre kelimeye farklı anlamlar yükleyen bir sözlüktür. Ağızlar, standart dile göre esnek kuralları ihtiva ederken ağız sözlükleri de genel sözlüklere göre daha geniş anlamları ihtiva eder. Bir metinde ağız kullanımı sözcüklerin standart dilden farklı anlamlarda kullanılmasını sağlayarak sınırlanmış anlamını genişletir. Genel sözlüklere ve ağız sözlüklerine yeni anlamlar eklendiğinde kavramlar ve nesneler daha geniş anlamları karşılar. Bu manada bir metnin tam anlaşılması için sözcügüün genel sözlükteki anlamının yanında hem metin bağlamındaki anlamı esas alınmalı hem de ağızlara ait bir sözcükse ağız sözlüklerine bakılarak karşılığı bulunmalıdır. Metin içinde karşılaşılan anlamı sözlüklerde bulunmuyorsa yeni anlam fişlenerek sözlüğe eklenmelidir. Bu manada metin içinde ağız kullanımının incelenmesi hem ağız sözlüklerinin hem de genel sözlüklerin kapsam alanını genişletir (Akar, 2009a: 3,8). Metinlerde ağız kullanımı kültüre ait malzemenin ortaya çıkarılması ve aktarımının sağlanması açısından da önemlidir.

\section{Bekir Yıldız ve Hikâyelerinde Ağız Kullanımı}

\subsection{Bekir Yıldız kimdir?}

1933 yılında Urfa'da doğan yazar, babasının görevi nedeniyle birçok şehir dolaşır. Sırayla Adana, Mersin ve İstanbul Sanat Enstitülerinde, ardından Matbaacılık Okulu'nda eğitim görür. 1957'de Güler Hanım'la, 1979'da Oya Hanım'la evlenir. 1962'de işçi olarak Almanya'ya gider. 1966'da İstanbul'a döner. Dizgi makinesiyle döndüğü İstanbul'da, kurduğu Asya Matbaasını yönetir. Yazarlık hayatına "Türkler Almanya'da" romanıyla başlayan Yıldız, asıl çıkışını 1968'de yayımladığ "Reşo Ağa" adlı öykü kitabıyla yapar. O zamana kadar işlenmemiş bir yöreyi, o yöredeki toplumsal ilişkileri, töreleri, ağalık düzenini konu alan kitap okurun ve eleştirmenlerin yoğun ilgisiyle karşılaşır. Yıldız, süslü anlatımdan kaçınarak, anlatmak istediğini yalın bir dille verir. Öykü, roman, röportaj ve çocuk kitapları olmak üzere farklı türlerde birçok eser yazar. Öykülerini yazarken verilmek istenen gerçeğin dolaysız bir biçimde ortaya konması gerektiğini savunur. Gerçekleri apaçık ortaya koymakla okuru uyandırmayı ve etkilemeyi düşünür. Salt bireyi ele almaktansa, birey veya bireyler üzerinden toplumsal olana öykülerinde yer verir. Üç çocuk babası olan Yıldız, 8 Ağustos 1998'de yaşamını yitirir. Yazar, "Kara Vagon" adlı eseri ile 1968'de öykü dalında May Edebiyat Ödülü'nü alır. "Kaçakçı Şahan" adlı öyküsü ile 1971'de Sait Faik Hikâye Armağanı'nı, “Darbe" adlı romanı ile 1990'da Milliyet 
Yayınları Roman Yarışması'nda birincilik ödülünü alır. "Allah'ın Gölgesinde Koşanlar" adlı röportajı ile 1991'de Yunus Nadi Röportaj Ödülü'nü layık görülür (Baskak 2008: 1-5; Yıldız 2006: 1). Çeşitli dergi ve gazetelerde yazıları, röportaj ve hikâyeleri yayımlanır. Bedrana ve Kara Çarşaflı Gelin adlı hikâyeleri sinemaya uyarlanır (Aydın 2013: 4; Yıldız 2006: 1). Yıldız'ın hikâyeleri iki ayrı yoldan ilerlemekte, fakat vermek istediği mesajın tek bir odağı bulunmaktadır. İlki, çocukluğunun geçtiği Güneydoğu Anadolu'daki insanın hayatına katı, acımasız ve giderek şiddete varan bir disiplinle egemen olan törelere sıkı sıkıya bağlı toplumsal yaşama biçimini işleyen hikâyeler; ikincisi bu toplumsal yaşama biçiminden çıkıp Almanya'ya göç ederek farklı bir toplumsal örgütlenmenin getirdiği, yine sert ve acımasız ama başka bir düzeyde gerçekleşen kurallara ayak uydurmaya çalışan insanları işleyen hikâyelerdir (Baskak 2008: 11; Özer 2007: 65). Öykücülük yönü ağır basan ve Türk Edebiyatında sosyal-gerçekçi çizgisiyle varlığını kabul ettiren yazar, öykülerinde Anadolu insanının yaşamını, töreler karşısındaki tutumunu, ağa-köylü ilişkilerini, kaçakçılığı, kan davasını, kırsal kesimden kentlere ve Almanya'ya çalışmaya giden insanların bunalımını ve evlilik kurumunun çarpık yönleri gibi konuları işler (Baskak 2008: 1; Özer 2013: 118). O kuşağının diğer yazarları gibi içe dönük, bunalımcı eserler vermek yerine, toplumun kanayan yaralarını, olumsuzluklarını ve kimsenin dokunmaya cesaret edemediği kurumları eleştirir (Aydın 2013: 9).

\subsection{Hikâyelerinde dil kullanımı}

Bekir Yıldız öykülerinde sade bir dil kullanarak, genellikle süssüz, anlaşılır ve yalın bir anlatımı tercih eder. Anlatım tekniği bakımından konuşma havasına has özensizlik ve savruk bir anlatımı vardır. Yıldız, halkın konuştuğu gibi yazma yoluna giderek okuyucunun eserlerde kendisini bulmasını ve karakteri daha iyi anlamasını sağlamaya çalışır (Özer 2013: 120). Eserlerinde Türkçe kelimeler kullanmaya dikkat eden yazar, "Şair Ana" adlı öyküsünde Arapça ve Farsça sözcüklere yer verir. Diğer öykülerinde ise Arapça sözcük sayısı azdır. Almanya'da geçen öykülerinde ise Almanca sözcüklere rastlamak mümkündür. Kahramanlara verdiği adlar genellikle yöre insanına ait isimlerdir. Almanya'daki hikâyelerinde Almanlara da yer verir (Baskak 2008: 166-170).

Güneydoğu'da geçen birçok öyküsünde konuya bağlı olarak halk dilindeki benzetme ve deyişleri anlatımına katar. Öykülerinde Güneydoğu Anadolu insanını çok fazla anlatan Yıldız, özellikle diyaloglarda ve iç monologlarda yerel dil kullanımına başvurur. Nesnel bir gerçeklikle yazdığı hikâyelerindeki diyaloglar olayın dramatize edilmesi bakımından gayet ayrıntılı ve nettir, bu yüzden yerel sözcüklere sıkça rastlamak mümkündür (Baskak 2008: 166-170). Yerel dili, öykü kişilerinin sosyokültürel yapılarına ve memleketlerine göre kullanır. Ağızlardan, bölge insanının duygu ve düşünce tavrını, en iyi biçimde anlatan diri bir motif olarak yararlanır. Ağızlar, yazarın "Reşo Ağa", "Kara Vagon", "Kaçakçı Şahan", "Sahipsizler" ve "Beyaz Türkü" adlı eserlerindeki öykülerinde belirgin bir biçimde kullanılmıştır. Bu öykülerde okuyucu standart dilde kullanılmayan birçok sözcükle karşılaşabilir. Bu ağız Güney Doğu Anadolu Bölgesine, özellikle Urfa çevresine ait bir ağızdır. Yıldız'ın öykülerinde, yerel dil kullanması olayların ve kahramanların somutlaşmasında önemli rol oynar. Çünkü öykülerde konuşan kişilerin olaylar karşısındaki durumu, bilinç düzeyi veya ruh hali kullandığı sözcüklerden anlaşılmaktadır (Baskak 2008: 170-174). Yazar eserlerinde ağızlara, dikkat çekmek amacıyla yer vermez, düşündüklerini daha gerçekçi bir biçimde aktarmak için ağızları bir araç olarak kullanır. Bununla birlikte sosyal meseleleri ve bazen de toplumda yaygın olan bir yanlış anlayışı öne çıarmak amacıyla yerel dilden yararlanır (Aydın 2013: 2). 


\section{Bekir Yıldız'ın Öykülerinde Ağız Kullanımı}

Kendini Toplumcu-gerçekçi olarak tanıtmış yazarların birçoğu eserlerinde yerel dili sıkça kullanırlar. Yukarıda bahsettiğimiz gibi Bekir Yıldız da bu yazarlardan biridir. Öyküleri çeşitli yönlerden incelenir, fakat kullandığı dili üzerine ayrıntılı bir çalışma bulunmamaktadır. Bu bağlamda çalışmamızda nitel araştırma yöntemlerinden doküman analizi kullanılarak Yıldız'ın hikâyelerindeki ağız kullanım derecesi ortaya çıkarılmaya çalışılacak ve ağız araştırmalarına katkısı değerlendirilecektir. Materyal olarak en çok bilinen eserleri olmasından ve anlatımlarında yerel dil kullanım oranının fazla olmasından dolayı "Reşo Ağa, Kaçakçı Şahan ve Alman Ekmeği" adlı hikâye kitapları kullanılmaktadır. Aynı zamanda hem yurtlarında yaşayan halkın anlatıldığı öyküler hem de gurbete çıkıp İstanbul ve Almanya'da yaşayan insanların anlatıldığı öyküler tercih edilmektedir. Böylelikle toplumsal yapı değişikliğine maruz kalan insanların diğerlerine göre dillerindeki farklılaşmalara da değinilebilecektir.

- Reşo Ağa: Yazarın bu eserinde Reşo Ağa, Kesik El, Pala Hamo, Düdüklü Tencere, Sucukçu, Aç-Kapa, Yorulmayan Adam, Üç Bit, Ayağa Dayak, Öl Ana adında on öykü bulunmaktadır. Öykülerin ilk dördüne Güneydoğu insanının töreler ve ağa zulmü karşısında düştüğü durumlar ve kan davası konu olur. Diğer öykülerde ise kentteki insanın yaşam kavgası, kentteki köylünün dramı ve evlilik kurumunun aksaklıkları anlatılır. Üç Bitte ise kurulu düzen eştirilir.

- Kaçakçı Şahan: Bu kitapta Gaffar ile Zara, Büyük Yas, Zırhlı Şamı, Güzel Parmaklar ve Kaçakçı Şahan adında beş öykü bulunmaktadır. "Gaffar İle Zara"da ağa zulmü ve işsizlik nedeniyle Almanya'ya yapılan dış göç anlatılmaktadır. Diğer öykülerde feodal ve ilkel toplum düzeninde benlikleri yok edilmiş insanların, içinde yaşadıkları toplumun sert ve acımasız kurallarına boyun eğişi anlatılır (Baskak 2008: 6).

- Alman Ekmeği: Kitapta, Ekmekle Körebe Oynayanlar, Kadınlarımızın Kırkta Biri Almanya İçin Gebe, Ailenin Böylesi, Otto'nun Bacakları Kimin Kasasında, Rahibelere Kapıcılık Yaptırıyor Fabrikatörler, Hitler'in Sığınağında Bir Fadime, İyilik Yargılanıyor, Koku Sızdırmayan Tabutlar, Yiyenler ve Alanlar, Dünyanın En Büyük İspiyon Şebekesi, Masalara İğnelenmiş Pazular, Babam Feleğin Üstüne Yürüyor ve Yanı Başımızdan Türkler Geçiyor adında on üç öykü bulunmaktadır. Bu öyküler Almanya' da geçmektedir.

Bu bağlamda üç hikâye kitabında toplam yirmi sekiz hikâye incelenmektedir. Bu öykülerde geçen ağızlara ait unsurlar tespit edilerek ve dilbilimsel bir sınıflandırılmaya tabi tutulmaktadır. Ağız çalışmalarında eldeki dokümanlar fonoloji, morfoloji, sözdizimi ve söz varlığı yönünden incelenmektedir. $\mathrm{Bu}$ sebeple eldeki veriler bu disiplinlere göre incelenmiştir. Metinlerde fişlenen malzeme dâhil edildiği sınıflandırılma altında verilerek gösterilmiştir. ${ }^{1}$

\subsection{Fonolojik Özellikler}

Ağızlar ile standart dilin fonem dağarcığında bulunan kapalı $e$ (é) ve geniz $n$ ( $\eta)^{\prime}$ si gibi az sayıda ses dişında önemli farklılıklar yoktur. Bu sesler bütün ağızlarda fonem değildir. Fonolojik açıdan ağızlarla standart dil arasındaki asıl ayrım, seslerin farklı gelişme basamaklarında yer almalarıyla ortaya çıkmaktadır. Ünlü, ünsüz uyumları ve çeşitli nedenlerle gerçekleşen ses olayları, farklılıkta önemli rol oynamaktadır. Ağızlara özgü sesler, standart alfabenin verdiği imkânlar ölçüsünde edebi metinlere yansıtılır. Standart alfabede karş1lığı bulunan sesler yazıda gösterilirken, karşılığı bulunmayan sesler, fonem de olsalar gösterilememektedir. Çeşitli nedenlerle ortaya çıkan ve bazı ağızlar için tipik olan ara sesler,

1 Örnek malzeme, bulunduğu hikâye kitabı/geçtiği öykü/sayfa numarası: habar RA/DT35 RA: Reşo Ağa; KŞ: Kaçakçı Şahan; AE: Alman Ekmeği. 
kendilerine en yakın olduğu düşünülen sesi gösteren harfle verilir. Edebi metinlerde başarılı bir biçimde aktarılan fonolojik ögeler arasında, bazı ağızlar için tipik olan ses uyumundaki farklılıklar yer almaktadır (Demir 2009: 4).

1. Alınma kelimelerde ünlü incelmesi ile meydana gelen uyum değişimi: Alınma kelimelerde genellikle DGA2nda incelmeler görülmektedir. BGA'nda ise kalınlaşma hâkimdir. Metinlerde incelmelere rastlanıldığı gibi kalınlaşmalara da rastlanmaktadır. Fakat kalınlaşmalar daha yoğun kullanılır. Bu benzeşme Karhan'ın eserinde BGA'na özgü bir değişim olarak ifade edilir (Karahan 2011: 15). Bu kullanımları BGA'na yakın yerlerde de bulmak mümkündür. Bununla birlikte yazarın Adana, Antep ve Mersin'de yaşadığı düşünüldüğünde dilinin etkilenmiş olması muhtemeldir.

gayrı RA/7,KŞ/GZ40, madam, vazifamiz RA/PH20, mısafirımsız RA/PH26, zatan, marıfatın RA/PH27, habar RA/DT35, yanı KŞ/GZ16/32/74, halınız KŞ/GZ17, zahar KŞ/GZ21, kuvvatliymış, kuvvatım KŞ/GZ26/29, mavı KŞ/ZŞ56, asalatlı, KŞ/ZŞ59, ahırzaman KŞ/GP74, emme RA/9, emmevelakin RA/PH23, ümmanin RA/9, gevvat RA/PH27, KŞ/GZ28/ZŞ56

2. Türkçe sözcüklerde meydana gelen kalınlaşmalar: ataş $R A / P H 27, K S ̧ / G Z 29 / 62$

3. Arka damak ünsüzü $\mathbf{k}^{\prime}$ nın önseste korunması: Bu ses DGA'nın 1. Grubunda korunmaktadır (Karahan 2011: 65).

kardaşıysam RA/KE20, kardaşıma KŞ/GZ40, kapı, karı, KŞ/GZ23, kız RA/8, kuvvatllymış, kuzu kısmı kurdun KŞ/GZ26/37

\section{4. $\mathbf{k}>\breve{\mathrm{g}} / \mathrm{g}, \mathbf{h}>\breve{\mathrm{g}}, \breve{\mathrm{g}}>\mathbf{k}$ değişimi}

heyvă̆ KŞ/GZ11, vă̆ benim hayırsız oğlum vağ KŞ/GZ20, Angara KŞ/GZ15/25, poğa, poğ poğuyla, poğunu KŞ/GZ16/17/25/37/59, döküşsün, döküşmüştü KŞ/ ZŞ60

5. Belirli bazı kelimelerde ön ses "y" ünsüzünün düşmesi: DGA'nda da görülen bir ses hadisesidir (Karahan 2011: 33).

igirmi KŞ/GZ16

6. Arapça ve Farsçanın ünlü ve ünsüzlerde etkisi: Arapça ve Farsçaya ait tipik "ayın, hemze ve k" gibi seslerin DGA'na etkisi kaçınılmazdır (Karahan 2011: 62). Yazar bu sesleri belirtecek işaretler vermemiştir. Çünkü ağız kullanımı onun öncelikli amacı değil, aracıdır.

7. Kalınlaşan ek ünlülerinin sebep olduğu kalınlık-incelik uyumsuzluğu: DGA'nın bir kısmında çeşitli sebeplerle ortaya çıkan ünlü kalınlaşması kalınlık-incelik uyumunu bozmaktadır. Bazı değişimler arka damak ünsüzlerinin etkisi ile meydana gelebilmektedir. $\mathrm{Bu}$ hadiseye DGA'nın 1. Grubunda Urfa, Elazığ, Erzincan ağızlarında rastlamak mümkündür (Karahan, 2011: 58). Aynı zamanda, arka damak ünsüzü ğ'nin ince ünlüleri kalınlaştırması BGA'nda da görülebilmektedir (Karahan 2011: 172).

bekliyacă̆ız RA/PH27, gideceğam, sürecă̆am, gidecaksan, etmiyecağam KŞ/GZ14/20/26/37/40/80, saatta RA/KE17

8. Arka ve orta damak geniz ünsüzü " $y$ "nin korunması veya kaybolması: $n>n, y>y$ n>y değişmesine Urfa merkez, Ceylanpınar ağızlarında çokça rastlanmaktadır (Karahan 2011: 19). Metinlerde " $n$ " sesi gösterilemediği için bu sesin varlığı hakkında metne dayanarak bir yorum yapmak olanaksızdır. Fakat "n" sesi oldukça fazla kullanılmıştır. Aynı zamanda DGA'na özgü "y" sesine de rastlamak mümkündür.

Kulaklarlyza, diliyiz, gözüyüz, emriy $R A / 9$, babay $R A / 10 / 17$, hepiyiz $R A / P H 23$, tabancayın, herifiyi $K S ̧ / B Y 49 / 51$

2 Metinde Doğu Grubu Ağızları DGA, Batı Grubu Ağızları BGA kısaltmalarıyla gösterilmektedir. 
9. Tonlulaşma hadisesi: Hece sonunda ya da ortasında rastlanmaktadır. südün RA/7, tahdda KŞ/GP72, Angara KŞ/GZ15/25

10. Ünlü ve ünsüz türemesi: Genellikle bu ses türemeleri yabancı sözcüklerde karşımıza çıkmaktadır.

suval RA/8/10, KŞ/GZ17/25, Alaman KŞ/GZ23/25/35, rüsvay KŞ/GP74

11. Ünlülerde görülen genişleme:

eyi RA/9, KŞ/GZ19/25/58, heç RA/10, KŞ85/GZ18/49, şeher KŞ/GZ30, get KŞ/ZŞ56

12. Ünlü-ünsüz düşmesi/hece kaynaşması:

ora-bura: RA/ 9/27, netmeli: RA/KE15, dakkadan RA/9, nere RA/KE17, burda RA/PH22, ordan ora KŞ/GZ23, töbe KŞ86/GP74, kulaklarıyza RA/9

13. Ek ünlülerinde darlaşma: Olumsuzluk ekinin ünlüsü $y^{\prime}$ sesinin etkisi ile darlaşmaktadır. Standart dile uygunluk göstermekle birlikte şahıs ekinin genişlemesi sebebiyle ünlü uyumlarına aykırı bir kullanım ortaya çıkmaktadır. Bazı sözcüklerin kök seslerinde de darlaşma olduğu görülmektedir.

tüketmiye: RA/PH23, ağlamıyam KŞ/GZ312, tanımıyam KŞ/87

14. Ünlülerde yuvarlaklaşma: Genellikle dudak ünlülerinin etkisi ile düz-geniş ünlüler yuvarlak-geniş ünlüye; dar-yuvarlak ünlüler, geniş-yuvarlak ünlüye; dar-düz ünlüler, dar yuvarlak ünlüye dönüşmektedir.

babo RA/PH24/27/35/37, KŞ/GZ18/32/40, KŞ/ZŞ56/59, bösböyük RA/DT28, KŞ/GZ26, möhör KŞ/GZ32, babom KŞ/GZ41, hökümsüz RA/7, zukkum, dödüklü RA/DT33

15. Kelime başında ünsüz türemesi

heyvă̆ KŞ82/85/GZ11/BY51/ZŞ58, hıyanatlık KŞ/ZŞ59

16. Göçüşme hadisesi: DGA' nın tipik özelliği olmasına rağmen metinlerde tek bir örnekle karşılaşılmaktadır.

Aznavur: kinci, gaddar, azgin RA/10

\subsection{Morfolojik Özellikler}

Morfolojik özelliklerden yararlanmak metinde ağız kullanımının en kolay yoludur. Özellikle çok varyantlı şimdiki zaman ekinin farklı biçimleri, gelecek zaman ekinin kısalmış biçimleri, geniş zamanın hem yapısında hem de işlevindeki farklılıklar, şahıs eklerindeki değişimler gibi morfolojik farklılıklar bu metinlerde de dikkat çekmektedir.

1. Şahıs zamirlerinin yönelme hali çekimindeki değişmeler: DGA'larında çokça dikkat çeken ve bu ağızlara özgü kullanım şeklidir (Karahan 2011: 35). Eldeki metinlerde tek biçimine rastlanılmaktadır.

siye $\mathrm{RA} / \mathrm{PH} 27$

2. Zamir kökenli çokluk 2. şahıs eki ile bildirme ekinin yapısı: Yazı dilinde "-sXnXz" biçiminde olan bu ekler Anadolu ağızlarında yapı bakımından gösterdiği çeşitlilikten dolayı ağızlar içinde ayırıcı bir özelliktir. DGA'larında ek -sIz biçimindedir (Karahan 2011: 37). Metinlerde bu eke rastlanmaktadır.

bilesiz, çıkarasız RA/9, edesiz, mısafırımsız RA/PH24/26

3. Şimdiki zaman ekinde meydana gelen değişmeler: Şimdiki zaman eki olan "-yor" ağızlarda çeşitli ses değişmelerine uğrar. DGA'da bu değişmelere çokça rastlamak mümkündür (Karahan 2011: 43). DGA'na paralel olarak metinlerde ekin -(I)y, -i, -e şekline yer verildiği görülmektedir.

söylisen, geçiyler, göremiyem, soruysan, anlıy mısan RA/KE7-19, çıkarıysan, sıkıysan, geliysen, görüysen, varıy ml, atıylar, çevirmiy, fokurdıy, çekiy, gidiyem, deyisen, diyem RA/PH24-27, örtmiy KŞ7, biliyem, istemiyem, açıysan, belliy, deyiler, korkuyam, çıkyam, gidiysen, düşünüyem, bilisen, gitmiy, 
istiyem, deyi KŞ/GZ13-49, geliy, istemisen mi, salıyam, istiysen KŞ/ZŞ58/59/62/65, beceremiyem, yapryam, gelemi KŞ/GP/6970/74, çekiliyem KŞ/82.

4. Duyulan geçmiş zaman ekinin tek şekilli olması: DGA'nda genellikle ek tek şekillidir fakat metinlerde ekin BGA' ndaki gibi çok şekilli örneklerine de rastlanmaktadır (Karahan 2011: 47).

duymuşam RA/KE18, başlamışam RA/PH25, hoş gelmişsen, olmuşsan, istemişem, yalvarmışam, etmişem, salmışam, çekmişem, bulmuşam, vermişem, almışam, dönmüşsen, tutturmuşsan, düşmüşem, gitmişem, anlamışam, vermişsen, uyumamışsan, demişem, söylemişem yapmışam, oturmuşsan, büyümüşem KŞ/GZ12/14/29/30/33/40, kalmışsan, görmüşem, geçirmişsen KŞ/ZŞ58, sarmamışsan, uyumuşam, eskimişem KŞ/GP/7072.

5. Teklik ve çokluk 1. şahıs emir eklerindeki ses değişmeleri: Yazı dilinde "-AyIm, AlIm" olan bu ekler ağızlarda farklı yapılarla karşılanır (Karahan 2011: 49). DGA'nda -Im, -Am, -Ak biçiminde kullanılan eke metinlerde de rastlanmaktadır.

bilem RA/7, gidem RA/DT28, kalkam, pişirem, bakak RA/DT35, gidim, alım KŞ/GZ13/18, öpüm KŞ/GZ19/GP71, diyek KŞ/GZ33/GP71, olam KŞ/GP74, geberip gidem RA/KE17, klyman RA/10.

6. İstek eki -a/-e' nin işleklik derecesindeki farklılıklar: DGA'nda bütün şahıslarda işlek olarak karşımıza çıkar (Karahan 2011: 51). Metinlerde de kullanılmaktadır.

bilesiz, çıkarasız, kurbanın olam, ola, RA/KE/9/19/DT35, sağolasan, posun devrile, getiresen, bilesen, KŞ/GZ16/27/38/58/83.

7. Teklik ve çokluk 1. şahıs olumsuz geniş zaman ekinin yapısı - DGA'nın 2. Alt gruplarında -mAzAm/ -mAzIk eklerine rastlamak mümkündür (Karahan 2011: 74). İncelenen metinlerde de karşımıza çıkar.

inmezik KȘ/ZȘ59

8. Zamir kökenli teklik 1. ve 2. şahıs ekleri ile bildirme eklerindeki ses değişmeleri: $\mathrm{Bu}$ ek DGA'nda -Am, -sAn biçiminde geniş ünlülü kullanılır. 1. Grupta bu yapı düzenli ve kurallı bir biçimdedir (Karahan 2011: 70). Metinlerde DGA'na ait en çok bu kullanıma rastlanır. Aynı zamanda Erzincan yöresi ve BGA'larında görülen gelecek zaman çekiminde 2. Teklik şahsın geniş ve kısalmış biçimi de kullanılır (Günşen 2006: 65-66).

dönecem, söylisen $R A / 7 / 9$, ulumadasan, vermeyecen, giyecen, göremiyem, varacan, soruysan, kaçakçıyam, duymuşam, etmelisen RA/KE14-20, çıkarıysan, söylisen, değilem RA/PH23, ederem, olmalısan RA/DT28/35, nasılsan, tanıram, yumaram, haklısan, haklıyam, düşünüyem, anlaram, bilisen, uğramalıyam, er olmalısan, asacaksan, basarsan, gidiysen, peşindeyem, alacağam, sürecağam, yaptıracă̆am, gidecek misen, item, anzavurlaşıysan, toprağam, yemişem, ağlamadasan, aparır mısan, okuyacağam, yalvaracă̆am, salacă̆am, kullanırsan, hatunumsan, binecă̆am dönmelisen, oğlumsan, gidiyem, gidecă̆am, yapacaksan, çalışacağam, alıram sızlamayacaksan, olacaksan, bilirsen KŞ/GZ12-40, görmüşem, geçirmişsen KŞ/ZŞ58, eskimişem, hastayam, tanımıyam KŞ/87.

9. Gelecek zaman ekinin yapısındaki değişmeler: Gelecek zaman ekinde -k ötümsüz sesi

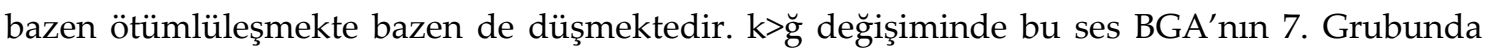
bulunan Birecik, Halfeti ve Adıyaman yörelerindeki gibi kalınlaşma eğilimindedir (Karahan 2011:174). Metinde gelecek zamanın bu şekillerine de rastlanılır.

salacan ora-bura RA/12: (Bu örnekte gelecek zamandan çok bir emir ifadesi vardır.), dönecem, vermeyecen, giyecen RA/9/KE15/17, taşıracağsan, kullanacan RA/PH23/24/35, bekliyacağız RA/PH27, varacan, er olacan, diyecen, atacan, gideceğam, çalışacağam alacă̆am, asacaksan, olacaksan, KŞ/GZ1420-25.

10. Geniş Zaman Ekindeki Değişmeler: Geniş zaman ekindeki $-r$ sesinin kurallı bir biçimde düşmesine genellikle BGA'nın bazı alt gruplarında rastlanmaktadır (Karahan 2011: 
129). İncelenen metinlerde sadece bir örnekte rastlanmaktadır.

avradı sayılın RA/KE18.

11. Araç durum ekinin kullanılması: $-n,-1 A n<i l e+n$ araç durum ifade eden ekler Anadolu ağızlarında sinırlı sayıda ve zamanla alakalı sözcüklerde görülür (Buran 1996: 236). Ekin standart dilden farklı kullanımlarına metinlerde rastlamak mümkündür.

durmaylan, intikamlan RA/PH22/23, yayan mi, eşeklen mi, kümeylen, olmuşlan, hemin de vallah hemin de billah KŞ/GZ22/27/37/41.

12. Şimdiki zaman eki -mAdA' nin kullanılması: Metinlerde ek sıkça kullanılır. Eklendiği cümleye geniş zaman ifadesi katmaktadır.

firlanmada, itibar etmemede, yapmada, dolanmadayiz, gelmedeymiş, yatmadasan, oturmada, gitmedesiniz, ağlamadasan, akmada, firlatmada, almada, belletmede KŞ/GZ13/19/20/25/28/31/32, ateşlenmede KŞ/BY47.

13. -AndA ekinin kullanımı: -dığı zaman anlamı veren ek standart dilde kullanılmamakta fakat metinde sıkça görülmektedir. Ek daha çok Azeri Türkçesinde ve Eski Anadolu Türkçesinde kullanılır (Korkmaz 2003: 946; Karasoy 2016: 11).

kıtlık olanda, hastalık olanda, namusu yere düşende, dönende KŞ/GZ15-17/40

14. Zarf kullanımı: Çeşitli zaman bildiren sözcüklere ve zamirlere bazı ekler getirilerek zarf yapılır. Bu kullanımlara standart varyanta rastlanılmamaktadır.

demincek, devriki sene, bulgurumuz nanca, hemin de, bunca trak me, hemin nereye gitmedesen, nanca dönerse, bunca olsun KŞ/GZ17/18/24/26/28/30/31/32/40, KŞ/GZ40, KŞ/GZ40, hemencecik KŞ/GP72.

15. Hal Eklerindeki Değişmeler: Genellikle işaret zamirinin üzerine eklenen bazı hal ekleri düşme eğilimindedir. Sözcüğün bünyesinde bulundurduğu yön gösterme durum eklerinin hissedilir varlığından dolayı sözcüğe eklenecek olan yönelme, bulunma eklerinin düştüğü görülür. Bu ifadeleri yön gösterme eklerinin kalıntıları karşılamış olabilir. Bunun yanında hal eklerinin eklenmesi ile sözcük bünyesinde bazı ses düşmeleri de görülmektedir.

ora-bura $R A 9 / 27$, herhal, nere $R A / K E 14 / 17$, burda $R A / P H 22$, ordan ora $K S S / G Z 23$

Metinlerde işaret zamirlerinin üzerine +lık yapım eki + bulunma durum eki gelerek yer bildiren sözcükler türetilir.

buralıkta, şuralıkta KŞ/GZ25/27

\subsection{Söz Varlığı Özellikleri}

Ağız örneklerine yer veren ilk metinlerden itibaren, yerel söz varlığı ögelerinden yararlanmanın, bir metnin ağız metni olduğu intibaını uyandırmada önemli bir yeri olduğu görülmektedir. Söz varlığında standart dilde hiç kullanılmayan kelimelere başvurulabildiği gibi standart dildekinden farklı söylenen kelimelere de yer verilebilmektedir (Demir 2009: 6). İncelediğimiz metinlerde yazar özellikle diyaloglarda ve iç monologlarda yerel söz varlığ kullanır. Yazarın özellikle yörenin insanı olması ve dile hâkim olması metin içindeki ağız kullanımının göze batmamasını ve ağız dokümantasyonu için kayda değer bir malzemenin ortaya çıkmasını sağlamaktadır. Standart dil kullanılmış bir metinden ziyade ağız kullanılan bir metin üzerine yapılan çalışmalar ağız sözlüklerine yeni veriler kazandırmaktadır. Metinlerde yöreye özgü sözcükler, deyimler, atasözleri, ünlemler, argo sözler, dualar ve beddualar vardır. Ağız kullanımı, Güney Doğu bölgesinin anlatıldığı hikâyelerde görülür. Fakat Almanya'da ve kentte geçen öykülerinde ağız kullanımına rastlanmamakta ve kahramanlar yaşadıkları yerin dilini benimsemektedir. Böylelikle göçle birlikte söz varlığı da değişir. 


\section{Yerel sözcükler}

Metinlerde ağızlara özgü sayabileceğimiz fişlenen yerel sözcük sayısı (119) yüz on dokuz dur. Bu sözcükler TDK'nın Derleme Sözlüğünden yararlanılarak incelenip, ait olduğu bölgeler tespit edilmektedir. Eserlerde Urfa, Diyarbakır, Elazı̆̆g, Erzincan, Erzurum, Muş, Van, Kars, Malatya, Gaziantep gibi DGA'nın konuşulduğu kesimlerde sıkça kullanılan sözcüklere rastlanmakla birlikte Sivas, Kırşehir, Kırıkkale, Hatay, Adana, Mersin, Kayseri, Niğde, Yozgat, Çorum gibi BGA'nın konuşulduğu yörelere ait sözcüklere de rastlanılmaktadır. Bu bölgelerin coğrafi yakınlıkları düşünüldügünde sözcüklerin dağılımındaki ve kullanımındaki ortaklık doğaldır. Bununla birlikte bazı sözcüklere ağızların kullanıldığı birçok bölgede rastlamak mümkündür. Derleme sözlügündeki incelemeler neticesinde kullanım alanı yaygın olan sözcükler de fişlemelere ve değerlendirmelere tabi tutulmaktadır. Böylelikle ağız ifadesi veren tüm verilerin incelenmesi amaçlanmaktadır. Aynı zamanda metinlerde geçen bazı sözcüklerin farklı anlamları da karşımıza çıkar. Malzemenin bir kısmına ise adı geçen sözlüklerde rastlanılmamaktadır.

Aba: uzun, yakasız üst giyimi RA/8 (Elazı̆̆, Erzurum, Isparta, Kayseri)

Aparmak: götürmek RA/10 (Diyarbakır, Malatya, Urfa, Kars)

Art: arka, geçmiş, geride kalan RA/DT29 (YAB $)$

Azap: tarlada çalışan erkek hizmetçi RA/DT28 (Urfa, Mardin, Adana, Sivas, Çorum...)

Azık: tarlaya götürülen yiyecek, RA/KE15 (YAB)

Aznavur: Kinci, gaddar, azgin RA/10 (Kırklareli, Konya)

Becerlemek: başarmak KŞ/GZ19 (Ankara, Denizli, Mŭ̆la)

Bellemek: tanımak, sanmak RA/KE16 (Malatya, Hatay, Sivas)

Beri: önce KŞ/BY49

Berk: sağlam, hızlı, iyi, çok KŞ/GZ13/17 (Adana, Gaziantep, Maraş, Hatay, Sivas)

Beter: çok RA/KE15 (Erzincan, Erzurum, Kars, Kütahya)

Birbaş: beraber, hiç durmadan, ara vermeden KŞ/GZ40/24

Burmak: ăgza kekre tat vermek KŞ/BY48

Celb çekmek: çă̆ırmak(kışkırtmak)RA/PH26 (Kars)

Dumanlamak: sigara içmek KŞ/GZ31

Cılk çıkmak: bozulmak, kızın bakire olmaması, hünersiz olmak RA/10 (Elazığ)

Cllık yel: güçlü esmeyen rüzgâr KŞ/GZ17

Cibinlik: sinek koruyucusu KŞ/GP72 (YAB)

Cincik: camdan yapılmış küçük ziynet eşyası RA/DT35 (Urfa, Çorum, Çanakkale)

Çalınma: sıkıntıda olmadan dolayı telaşlanma, korkma KŞ/GP69 (Hatay, Gaziantep)

Çöreklenmek: düşüp kalmak RA/KE18

Çörten: oluk KŞ/GZ26 (Antep, Maraş, Sivas...)

Çuha: kaba dokunuşlu keten giyisi (pantolon) (Erzurum, Kars)

Çünküme: çünkü KŞ/GZ24

Çüt: tarla, çift sürmek RA/DT33 (Erzincan, Elazı̆̆)

Devriki: gelecek KŞ/GZ18 (devliki: Gaziantep, Hatay; devrisi: Urfa, Erzincan, Sivas...)

Dirliksiz: geçimsiz KŞ/BY47 (Erzurum, Malatya, Hatay, Sivas, Mersin, Eskişehir...)

Don: iç çamaşır RA/8/14 (Diyarbakır, Elazı̆̆...)

YAB: Yaygın ağız bölgesi (Bu tip sözcükler TDK'nın Türkçe Sözlüğünde yer almaktadır. Ancak bu sözcükler, temsil ettikleri ağız bölgesinin söz varlığında yer almaları ve geniş (yaygın) bir kullanım alanına sahip olmalarından, aynı zamanda metinlerde ağız ifade eden cümleler içinde kullanılmalarından dolayı incelemeye dâhil edilmektedir. Ağız ifadesi olarak kullanılmış her bir sözcügün incelenmesi araştırmanın daha doğru sonuçlara ulaşmasını sağlayacaktır.) 
Döl/döllemek: insan ya da toprak tohumlamak RA/KE14/20, KŞ/GZ12 (Adana)

Düğ̈̈mlü ses: küskün, kısık mirıldanma KŞ/GZ32

Dürüm: yemek KŞ/GZ17 (Adana, Erzurum, Elazı̆̆g, Kırşehir)

Düven: ekinleri dövmek için kullanılan alet RA/KE18 (Kırşehir, Zonguldak)

Enik: çocuk KŞ/GZ17

Erişmek: büyümek KŞ/GZ24 (Adana)

Eskimiş: yaşlı KŞ/87

Esmek: savurmak KŞ/ZŞ55 (Elazı̆̆)

Essah: gerçek KŞ/GZ14 (Erzurum, Elazı̆̆, Malatya, Diyarbakır, Kırşehir)

Esvab: çamaşır RA/KE15

Fırlanmak: boş gezmek KŞ/GZ13 (Elazı̆̆, Malatya, Adana, Isparta...)

Fistan: kadin elbisesi RA/KE15 (Artvin, Zonguldak, YAB)

Gözlemek: beklemek RA/KE24 (Erzurum)

Güdük: kısa RA/AY91(Kayseri, Mersin)

Hampara: moloz KŞ/ZŞ56 (Gaziantep)

Hanek: söz KŞ/GZ13 (Bitlis, Urfa, Gaziantep, Maraş)

Hayad: avlu KŞ/GZ26 (Ankara, Amasya, Gümüşhane)

Hellemek: kuşlarn isteklendirmek 63KŞ/ZŞ62 (Gaziantep, Sivas, Yozgat)

Herif: koca, erkek KŞ/GZ35 (Diyarbakır, Erzincan, Erzurum, Kırşehir)

Herif̧̧ioğlu: hoşlanılmayan, kendini beğenmiş kişi KŞ/GZ25

Hoyrat atmak: mani, türkü söylemek KŞ/BY49 (Erzurum, Urfa)

Huylanmak: sinirlenmek, tedirgin olmak KŞ/GZ12 (Erzurum)

İgirmi: yirmi KŞ/GZ16 (Kars, Erzurum, Elazı̆̆)

İğdiş edilmek: değerini yitirmek $A E / D S ̧ 68$

İnhisar: tekel KŞ/GP70

İrkmek: biriktirmek, toplamak KŞ/GZ14 (Maraş, Gaziantep, Adana, Sivas, Çorum...)

Kaça kaça: koşa koşa KŞ/GZ32

Kara kefen: çarşaf KŞ/BY47

Kaşkaranlı̆̆ı: çok kararmak (?) KŞ/GZ22

Keçeleşmek: vücudun duyarsız hale gelmesi KŞ/GZ12

Kekka: oh ne güzel (alaylı)KŞ/GZ18 (Kakko: Elazı̆̆g, Malatya)

Kel: verimsiz (toprak)RA/DT28 (Maraş, Niğgde, İçel)

Kelli felli: gösterişli KŞ/GZ15(YAB)

Kemirtmek: ezdirmek KŞ/GZ26

Kendir: ip KŞ/GZ40 (Erzurum, Antep)

Kerkere: yaşl, yaşı geçmiş (hitap)KŞ/ZŞ59 (Urfa)

Kertik: çizgi, zaman KŞ/84

Kişelenmek: kovulmak KŞ/GZ34 (İçel)

Kongurdak: güvercinin ayağına takılan çan KŞ/ZŞ57 (Sivas, Isparta)

Körletmek: ışı̆̆ııı azaltmak KŞ/80

Kurban: arkadaş (hitap sözü) KŞ/GZ42

Kuşluk: sabahla öğle arası KŞ/GZ17 (Malatya, Sivas)

Kuzlamak: insan doğurmak (aşağılama) RA/KE14 (Hatay)

Kürelemek: atılmak, savrulmak KŞ/GZ23 (Urfa, Ankara, Niğde, Çorum)

Loğ taşı: silindir taşı RA/KE16 (Erzurum, Elazı̆̆, Afyon)

Nanca: ne kadar KŞ/GZ1, ne zaman KŞ/GZ24 (Erzurum, Elazı̆̆, Malatya, Hatay)

Neçek: başörtü KŞ/GP69 (Urfa, Elazı̆̆, Diyarbakır, Malatya) 
Nefeslemek: söylemek, konuşmak KŞ/GZ27

Nuh nebiden kalma: eskiden kalma KŞ/GZ34

Oba: köy KŞ/GZ27 (Erzincan, Sivas, Maraş, Tokat, Aydın)

Off etmek: izin vermemek RA/PH24

Ötelere sünmek: ileriyi, başka bir olguyu düşünmek KŞ/GZ26

Parlak çekmek: uçan güvercini indirmeye çalışmak KŞ/ZŞ57 (Adana)

Parpazlanmak: acıdan kıvranmak KŞ/GZ15 (Antep)

Pençe: avuç, parça KŞ/GZ11 (Adana: pança)

Pısmak: ürkmek, sinmek RA/PH26 (Kars, Kayseri)

Seğirtmek: koşmak KŞ/GZ32 (Antep, Çorum, Artvin)

Selmek: elemek/savurmak KŞ/GZ31

Sinamak: denemek KŞ/82 (Erzurum, Diyarbakır, Elazı̆̆)

Soluk vermek: zaman vermek KŞ/GZ16 (Ordu)

Sümsürük olmak: pısirık olmak KŞ/GZ13

Tahd: çardak KŞ/GP72 (Erzurum, Urfa)

Tanış çıkmak: tanıdık KŞ/86 (YAB)

Taramak: bakmak KŞ/88 (Niğde, Artvin)

Tay düşmek: berabere kalmak KŞ/ZŞ56 (Urfa, Elazı̆̆, Van, Maraş, Kars, Sivas, Samsun)

Tendirisli: sağlam, düzenli KŞ/GZ23

Terklemek: terk etmek KŞ/GZ14

Tez: çabuk, hızlı RA/8/9 (Diyarbakır, Elazı̆̆, Erzurum)

Tezek: yakmak için kurutulmuş hayvan gübresi KŞ/ZŞ62 (Elazı̆̆)

Timin: tahıl ölçeği KŞ/GZ18 (Diyarbakır, Elazı̆̆, Malatya, Antep, İçel)

Tokya: plastikten yapılmış terlik AE/DŞ67

Töz: kulak arkasındaki çukur yer KŞ/GZ23 (Antep, Hatay, Sivas, Adana, Eskişehir...)

Tuman: don, şalvar RA/8 (YAB)

Ufalta ufalta: yavaş yavaş KŞ/83

Uşak: çocuk KŞ/GZ20/11 (YAB)

Uzun çekmek: uzun sürmek KŞ/GZ21/22

Vinlamak: sinek sesi KŞ/GZ21

Vurmak: denk gelmek KŞ/GZ16 (Niğde)

Vuruşmak: savaşmak KŞ/GZ19 (Erzincan, Trabzon, Sivas, Eskişehir...)

Yalanmak: göze girip çıkar sağlamak için yalakalık yapmak KŞ/GZ11

Yanaşma: hizmetçi, sığıntı AE/EO8 (Hatay, Kars, Kayseri, Isparta, Muğla, Edirne)

Yassi: miskin, gevş̧ek KŞ/ZŞ62 (Urfa, Kars)

Yekinmek: bir eylem yapmaya davranmak RA/6/8KŞ/GZ22 (Erzurum, Elazı̆̆, Hatay...)

Yel gibi: hızlıca KŞ/GZ40

Yemeni: lastik ayakkabı KŞ/GZ26 (Elazı̆̆, Malatya, Diyarbakır, Antep, Hatay...)

Yüklük: yatak dolabı KŞ/GZ16 (Erzincan, Ordu, Uşak)

Zıbarmak: yatmak KŞ/GP72 (Elazı̆̆, Niğde)

Zırlanmak: ağlamak KŞ/GZ34 (Erzurum, Hatay, Elazı̆̆, Sivas, Niğde...)

Zıtlı: kavgalı KŞ/ZŞ55

Zibil: değersiz KŞ/GZ26 (Erzurum, Malatya, Antep, Ni⿱̆gde)

Zukkum: (aniden) zarar veren RA/DT33 (Erzincan, Isparta) 


\section{Deyim ve atasözleri}

İncelenen metinlerde altmış beş (65) adet deyime ve üç (3) adet atasözüne rastlanır. Fişlenen malzeme Bölge Ağızlarında Atasözleri ve Deyimler sözlüğünden yararlanılarak taranıp, verilerin ait olduğu ağız bölgeleri tespit edilmeye çalışılmaktadır. Fakat bu kaynakta deyimlerden yalnız birinin birebir karşılığı bulunmakla birlikte birçok deyimin farklı şekilleri karşımıza çıkar. Ö. Asım Aksoy'un Atasözleri ve Deyimler Sözlüğ̈̈ ${ }^{\circ}$ üzerinde yapılan taramalarda ise 8 deyimin adı geçen kaynakta yer aldığı görülür.

Aklı kurcalanmak KŞ/ZŞ58

Aklını yumurta sarısı ile beslemek KŞ/ZŞ59

Aklının tavanı çökmek KŞ/GZ35

Ardını unutmak: geçmişi, geride kalanları unutmak RA/DT26

Ayran delisi: aptal, bön olmak KŞ/GZ27

Bayrak açmak: başkaldırmak KŞ/GZ20 (ÖAAD,630<bayrakları açmak)

Bilmeceye düşmek: oyuna gelmek KŞ/ZŞ55

Bir parmağında on iş firlatmak: KŞ/GZ31

Birini hesaptan düşmek: öldürmek KŞ/GZ19 (ÖAAD,857, farklı manada kullanılmaktadır.)

Boğazlanmış tavuk gibi parpazlanmak: can çekişmek KŞ/85

Buz üzerine yazı yazmak KŞ/GZ23 (ÖAAD,668)

Dayağı çekmek: dövmek KŞ/GP73

Devenin büyüğ̈̈nü ahırda unutmak KŞ/GP70

Diline çiyanları salmak: RA/KE17

Dillerde bulaşığı kalmak KŞ/ZŞ59

Dillere destan olmak KŞ/ZŞ61 (ÖAAD,723)

Dona düşmek: doğum yapmak RA/KE14

Eline tutuşmak: elde etmek RA/9

Gönle gariplik çökmek KŞ/GZ12

Gözü ardına yapışık kalmak KŞ/GZ39

Gözü küllü: saf kimse KŞ/GZ29 (BAAD: 322,Gaziantep; Adana6)

Gözü yassı olmak: tepki göstermemek KŞ/GZ13

Günahtan temizlenmek: gusül almak KŞ/GZ22

Herifine dayanamamak KŞ/GZ23

Hoş mu, hamam buğu: her şey yolunda KŞ/GZ26

İki ayaklı keçi oynatmak: inatçı birine söz anlatmak KŞ/GZ19

Iki direği çatmışlar, avrat diye satmışlar. KŞ/GP73

Kaderi yanlış çalınmak: kaderi yanlış yazılmak RA/10

Kan sıçırtmak RA/PH27

Kederi düze çekmek: kederini azaltmak KŞ/GZ31

Kırk besmeleyle meydana gelmek: değerli, hatırı sayllır kutsal kişi olmak KŞ/GZ29

Kör ebem de yapar. KŞ/GP71

Kanı toprağa çözülmek: ölmek RA/PH24

Kiran girmek: bulunmaz olmak, yok olmak KŞ/GZ25 (ÖAAD:928, Elazı̆̆)

Koz bölüşmek: koz paylaşmak KŞ/ZŞ60 (BAAD: 355,Gaziantep)

Kulağın bir tözünden girip diğer tözünden çıkma KŞ/GZ23

4 BAAD: Bölge Ağılarında Atasözleri ve Deyimler

5 ÖAAD: Ömer Asım Aksoy, Atasözleri ve Deyimler Sözlüğü

6 Bölge halkından edinilen bilgidir. (Nuray Kaynak/Adana) 
Kulağına küpe olmak KŞ/GP70 (ÖAAD,943)

Kulak açmak RA/PH23

Kurban olmak KŞ/GZ37 (ÖAAD,945)

Kuş kadar beyni olmamak KŞ/GZ33 (ÖAAD,947)

Kuzu kısmı kurdun önüne çıkarsa sonu sarpa sarar. KŞ/GZ37

Mel mel bakmak: boş boş bakmak AE/EO8

Merakına gelmek: hoşa gitmek RA/PH24

Name salmak: mektup göndermek KŞ/GZ33

Namustan yana yiğit olmak: kadının namuslu olması RA/AY91

Namusuna leke çalmak: iffetsiz olmak RA/10

Obasını boşlamak: terk etmek KŞ/GZ14

Ölüm önünde yuvarlanmak: ölmeye yüz tutmak, debelenmek RA/PH24

Öz mezarlarıyla konuşmak: vicdanını dinlemek KŞ/85

Poğuyla gülle oynamak KŞ/GZ25

Sesi çapaklı olmak: sesi titremek, sesi çıkmamak KŞ/GZ35

Sesi lime lime olmak: sinirden, ezilmekten kesik kesik konuşmak KŞ/BY49

Sırrı kanlı olmak: kan davalısını öldürmek KŞ/GZ13

Sözcükleri teğellemek: akıcı bir biçimde konuşmak KŞ/GP72

Sözü düğ̈̈̈mlemek: konuşmayı tamamlamak KŞ/GZ13

Sözü yürütmek: söze devam etmek KŞ/ZŞ61

Taşkaleye gelmek: işi aceleye getirmek, telaşlanmak KŞ/GZ13

Tekmeler altında yoğrulmak: dayak yemek $R A / 7$

Tumaninı styırmak: zina yapmak $R A / 8$

Uykudan çözülmek: uyanmak KŞ/GZ21

Ya herro ya merro KŞ/ZŞ56 (ÖAAD,1101)

Yağ içmiş gibi yürümek: hızlıca, etrafa bakmadan gitmek KŞ/85

Yere sümük gibi yapışmak KŞ/GZ33

Yoluna kulak tutmak: gelmesini beklemek KŞ/BY49

Yüreği yarllmak: korkmak RA/7

Yüreğini serin tutmak $R A / 9$

Yüzü güllenmek: gülümsemek, sevinmek KŞ/ZŞ63

Yüzünü sarpıtmak: sonuçlarına katlanarak üzülmek KŞ/GZ14

\section{Argo, kaba söz ve küfür}

Yerel varyantın sıkça kullanıldığı metinlerdeki diyalog bölümlerinde on altı (16) adet kaba söz ve küfre rastlanmaktadır. Argo, kaba söz ve küfürler anlatılanların daha inandırıcı ve etkili olması için kullanılır. Bu sözler, kişilerin kültürel düzeylerini ve o an içinde bulundukları ruh halini yansıttıkları için öykülerde eğreti durmamaktadır. Bu sözcüklerin çoğunun geniş bir ağız bölgesinde kullanıldığ1 söylenebilir. Türk Argosu Sözlügünde ${ }^{7} 3$ adet argo sözcüğe rastlanmıştır. Bununla birlikte bazı sözcüklerdeki yöreye özgü sayılabilecek ses hadiseleri sayesinde DGA'larında sık görülen argo ve kaba sözler tespit edilmiştir.

Cakalı kimse RA/ÜB64/69 (TA:67), Çük KŞ/80, Dinsiz orospu KŞ/GP74, Erzikırık KŞ/GP73, kahpe, çüş, gavur dölü, orospu şahı, deyyus RA/7/8/1420/24, kafaları parlatmak RA/YA53, kapatma RA/ÜB64/69, keş: alkolik RA/ÜB63, kıç RA/AK44, koltuk meyhanesi RA/YA53 (TA:111), döl

$7 \quad$ TA: Türk Argosu Sözlüğü, Ferit Develioğlu. 
RA/KE14/20, KŞ/GZ12 (Adana), poğ, karı, herif, pezevenk, ă̆zına sıçaram KŞ/GZ13/23/28, ula kerkere KŞ/ZŞ59 (Urfa<hakaret>), viz gelmek RA/ÜB64 (TA:155)

\section{Dualar}

Metinlerde dua niteliğinde sayılabilecek tek bir örnek kaydedilir. Bu örnek anlam itibari ile kötü bir niyeti çağrıştırsa da metin bağlamından hareketle kahramanın ağzından çıkış biçimi dua niyetiyledir. Bu söz varlığı yöreye ait bir geleneği ve kültürün dil ile aktarımının açık bir örneğidir. Ülkemizde kan davalarının Doğu bölgelerinde yaygın olması, bu bölgelerde kan almanın olumlanarak dualarda yer almasına yol açar.

Yolunuz kanlı ola. RA/9

\section{Beddualar}

İncelenen metinlerde duadan çok beddualara rastlanır. Bu anlamda yedi (7) adet beddua fişlenmektedir. Genellikle ağa halkına, ebeveynler çocuklarına ve erkekler eşlerine beddua eder. Bu kalıplaşmış sözlerin çoğu geniş bir ağız bölgesinde yaygın olarak kullanılır. Serdar Bulut'un Anadolu Ağızlarında Kalıp Sözler ve Kullanım Özellikleri adlı tezinden yararlanılarak bedduaların hangi yörelere ait olduğu tespit edilmeye çalışılmaktadır. Bu bağlamda yaygın bir kullanım alanına sahip beddualar kullanıldığı görülür. Aynı zamanda yaygın olmayan ve kaynaklarda rastlamadığımız birkaç beddua, DGA konuşurları ile yapılan sözlü araştırma ile tespit edilmektedir. Kullanım alanlarının genellikle DGA'nın konuşulduğu bölgeler ve coğrafi yakınlığı olan alanlar olması dikkat çekicidir.

Boyun posun devrile. KŞ/GZ27, Canı çıasıca. RA/KE16 (SB:135, Erzurum, Elazı̆̆, Adanå), Gözü kör olasıca. KŞ/GZ13 (Osmaniye-Zonguldak, SB:34), Gözün önüne aksın avrat. KŞ/GZ35 (KırıkkaleAdana, SB:171), Küller başımıza. RA/6 (Kars, Ardahan, Urfa ${ }^{9}$ ), Ulan sıfatı batasıca. KŞ/ZŞ62 (Adı batasıca; Kahramanmaraş, SB:33), Yere giresice. RA/KE15 (SB'10:147, Malatya), Yere giresin. KŞ/GZ22 (Malatya, SB:147)

\section{6. Ünlemler}

Metinlerde on beş (15) adet ünlem tespit edilmektedir. Ünlemlerin çoğu DGA'larında

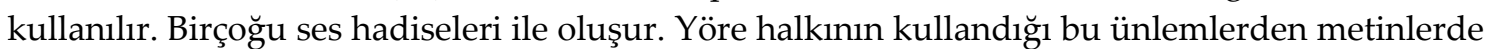
sıkça ve canlı bir biçimde yararlanılır. Özellikle gevvat, viş, vel, aney gibi ünlemlerin bu yörede canlı bir biçimde kullanıldığını söylemek mümkündür.

Viş ağam/anam, viş küller başıma RA/8KŞ/GZ13/24/27/31KŞ/BY47, vay babo vay RA/PH24/27/KŞ/GZ18/KŞ/ ZŞ56 (Van, Antalya, Kırşehir, SB:127), bu ne iştir lo, yalan mi lo. RA/PH25KŞ/BY49, vağ hayırsız oğlum vağ KŞ/GZ20, di (hadi) yekin KŞ/GZ22/25/32/70, vel: şaşkınlı ifade etmektedir. KŞ/GZ26/GP73, aney KŞ/GZ27/31, babolar: yanindakilere seslenmektedir. KŞ/ZŞ58, oşt köpek KŞ/GZ29, gidiyem ha! KŞ/GZ35, va... hatunumsan KŞ/GZ36, he vallah he billah KŞ/ ZŞ 59, hele vicdanına söyle. KȘ/GP74, na orda. KȘ/83, hemi: onaylama KŞ/GZ23.

\section{Yeminler}

Metinlerde iki (2) adet yemin etme kalıbı bulunur. Bulut'un eserinden yararlanarak sık kullanıldığı yöreler tespit edilmektedir. Bu kalıplara az ya da çok farkla tüm ağız bölgelerinde rastlanir.

Hemin de vallah hemin de billah KŞ/GZ41 (Diyarbakır, Erzincan, SB:175), he vallah he billah KŞ/ZŞ59 (Muş, Adıyaman, Erzurum, SB:175)

\section{Almanya'da geçen öykülerde söz varlı̆̆}

\footnotetext{
Bölge halkından edinilen bilgidir. (Emine Göztaş/Adana)

Bölge halkından edinilen bilgidir. (Cihan Oruç/Kars, Sedat Solgun/Urfa, Şahin Taşgülük/Ardahan)

10 B: Serdar Bulut, Anadolu Ağızlarında Kalıp Sözler ve Kullanım Özellikleri, Yüksek Lisans Tezi.
} 
Bölgesel dil kullanım farklılığı ile birlikte toplumda bürünülen her rol, her kimlik, her türlü sosyal ve kültürel zemin, ayrı bir dil kullanımını doğurmaktadır. Bu yüzden, bireyin dil kullanımı kendi bireysel farklılıklarına, toplumda üstlendiği rollere, sosyal hayattan etkilenme biçimine göre çeşitlilik gösterir. Yabancı bir kültürü benimseme veya bu kültürden etkilenme, beraberinde dil değişimi/karışımı, kod değişimi/karışımı gibi dil kullanım biçimlerini getirmektedir (Şengül 2009: 2178). Bu sebepledir ki Anadolu'dan Almanya'ya giden kahramanlar ağız kullanımına son vermekte, yaşadıkları coğrafyanın diline uygun bir tavır sergilemektedir. Yazarın Alman Ekmeği eserindeki öyküleri Almanya'da geçer. Bu metinlerde köy yaşamına ait söz varlığı bulunmaz, genellikle modern hayata dair sözcüklere rastlanır. Diyaloglarda standart Türkçe'nin yanında Almanca cümlelere ve kelimelere yer verilir. Yazarın dil kullanımındaki titizliği dil becerisinin yüksek seviyede olduğunu göstermektedir.

Amigo: İspanyollara sesleniş ünlemi AE/YA60, beatnik: dönemin hippilerine verilen isim RA/ÜB62, curuf: yanmış atık, çöp (Kapitalist ekonominin curufları) AE/YT90, exportçuluk: AE/KT57, faşing: eğlence yeri RA/DT33, halle: çalışma bölmesi AE/DŞ64, pfenning pfenning biriktirmek (Kuruş kuruş biriktirmek deyimini analoji ile yeni bir biçime büründürmüş̧ür.) AE/BF84, trevira takım: polyester kumaştan giysi RA/DT32.

\subsection{Söz Dizimi Özellikleri}

Bazı bölgelerin ağızları, standart dil ile karşılaştırıldı̆̆ında söz dizimi açısından önemli farklılıklar gösterir. Bu özellikle başka dillerle ilişkilerin yoğun olduğu bölgeler için geçerlidir (Demir 2009: 6). DGA'nda devrik cümlelere ve bildirme ekinin sıkça kullanıldığ 1 cümlelere rastlanmaktadır. Bununla birlikte metinlerde "ve de" yapısı ile kurulmuş birçok birleşik cümle dikkat çekicidir. DGA'nda vurgu ile sağlanan soru cümlelerine metinde rastlanılmaz.

Atın biri de yok meydanda. RA/7, Demeyecekler mi ve de düşünmeyecekler mi? KŞ/74, Dizinin dibine oturtmalıydı ve de vura vura belletmeliydi. KŞ/74, Gece ortanın çok berisindeydi henüz. KŞ/BY47, Kanlımağaraya ulaşmadan varın bana. RA/8, Kızı ă̆ası kurşunlamıştır. Gözlerin önüne mi akmıştır. Babam salmıştır, demiştir ki... KŞ/ZŞ59, Ulan avrat savuş karşımdan. RA/7, Yanında cıgara içerim mi hiç? KŞ/GZ16.

\section{SONUÇ}

Bekir Yıldız'ın eserleri üzerinde yaptığımız araştırmada üç hikâye kitabında toplam 28 öykü incelenmektedir. Taranan eserlerde Güney Doğu Anadolu Bölgesinde geçen hikâyelerin özellikle diyalog bölümlerinde ağız unsurlarına rastlanılır. Ağız kullanımı metne canlılık, inandırıcılık ve gerçekçilik kazandırır. Kahramanların ağzından kurumları, ağalığı, haksızlığı, şiddeti yermek için çıkan argo söz ve küfürler de metinlerde karşımıza çıkar. Yazar, köyde halkı yerel dille konuştururken kentte, özellikle Almanya'da insanları bulundukları toplumun yapısına uygun olarak konuşturmaktadır. Bu da yazarın çok yönlü bir dil kullanıcısı ve gözlemcisi olduğunu göstermektedir.

Bu çalışmada verileri sınıflandırmak için fonoloji, morfoloji, söz varlığı, söz dizimi ölçütleri esas alınarak inceleme yapılmaktadır. Bu bağlamda kullanılan ağız Leyla Karahan'ın sınıflandırması esas alındığında fonolojik ve morfolojik ölçütlere göre Doğu Grubu Ağızlarının 1. ve 2. Grubuna; Batı Grubu Ağızlarının 7. Grubuna ait özelliklerle örtüşür. Yazı dili alfabesinin sınırlı sesleri göstermesinden dolayı fonem düzeyindeki sesler ve yöreye özgü sesler tespit edilememektedir. Fakat bu bölgelere ait önemli ses hadiselerine eserlerde rastlanılır. DGA'nda çokça kullanılan göçüşme hadisesi tek örnekte karşımıza çıkar. Alınma kelimelerde DGA'na özgü incelmeden ziyade BGA'na özgü kalınlaşma hâkimdir. Bunun yanında diğer ses 
hadiseleri tipik DGA'nın özelliklerini taşımaktadır. Elde edilen veriler morfolojik açıdan incelendiğinde şahıs eklerinin durumu, şimdiki zaman, gelecek zaman, emir ve istek kipindeki kullanım biçimleri açısından DGA'nın özellikleri yansıtılmaktadır. Fakat duyulan geçmiş zamanın bu ağızların aksine BGA'ndaki gibi çok şekilli olduğu görülür. Bunu standart dilin etkisinin yanında, yazarın Mersin, Adana gibi BGA'nın konuşulduğu yerlerde yaşaması ve etkilenmiş olmasına bağlamak da mümkündür. Taranan materyaller söz varlığı açısından temel alınarak incelenmekte ve yerel sözcüklerin büyük bir bölümünün Elazığg, Erzincan, Erzurum, Muş, Urfa, Diyarbakır, Birecik, Van, Tunceli, Kars, Malatya, Gaziantep gibi DGA'nın konuşulduğu yörelere ait olduğu tespit edilmektedir. Aynı zamanda Sivas, Niğde, Kırşehir, Kayseri, Kırıkkale, Yozgat, Mersin, Adana, Hatay gibi BGA'nın kullanıldığı yörelere ait sözcükler de karşımıza çıkar. Anadolu ağızlarında geniş kullanım alanına sahip bazı yerel sözcükler eserlerde mevcuttur. Bu bağlamda 119 adet yerel sözcük tespit edilmektedir. Bununla birlikte 66 deyime, 3 atasözüne, 16 argo, kaba söz ve küfür bildiren sözcüğe, 1 dua, 7 bedduaya, 2 yemin ifadesine ve 15 ünleme rastlanmaktadır. Bu yörede kullanıldığı belirgin olan ünlemler dikkat çekicidir. Yerel sözcüklerin derleme sözlügünden farklı anlamlarda kullanılan biçimleri de karşımıza çıkar. Fişlenen deyimler sözlüklerle karşılaştırmalı incelendiğinde çoğunun bire bir aynısının bulunmadığı görülmekte hatta sözlüklerde yer almayan deyimler tespit edilmektedir. Söz dizimi açısından bakıldığında DGA'larında vurgu ile sağlanan soru cümleleri bu tip metinlerde karşımıza çıkabilir. Fakat taranan malzeme arasında bu tip cümlelere rastlanmamaktadır. Yine DGA'larında sıkça kullanılan devrik cümleler, belirgin biçimde kullanılmış bildirme kipli cümleler tespit edilmektedir.

Yazar anlatımını kuvvetlendirmek amacıyla ağızı araç olarak kullanmaktadır. Yani yazar ağızdan üslup açısından faydalanır. Ağız çalışmaları için ise bir ağıza yer vermiş edebi bir metin, onu taşıyan ve varlığını koruyan bir doküman niteliğindedir. Buna göre her iki disiplin birbirini araç olarak kullanmaktadır. Araştırma sonucunda edebi metinlerde ağız kullanımının ağız dokümantasyonu ve ağız incelemeleri açısından faydalı olduğu görülmektedir. Bu çalışma ile içinde ağız malzemesi barındıran metinlerin ağız belgesi olarak kullanılabilirliği ortaya çıkarılmaktadır. Metinlerin ses düzeyinde çok net değerlendirmeleri yapılamazsa dahi morfoloji ve söz varlığı düzeyindeki yararları küçümsenmeyecek kadar fazladır. Metinlerin unutulmuş, kullanılmayan, gözden kaçan söz varlığının ortaya çıkarılmasında incelenmesi gereken bir kaynak olduğu söylenebilir. Böylelikle metin incelemeleri, ağız malzemesi derleme amacıyla kullanılacak yöntemler arasında sayılabilir. Aynı zamanda bu tip çalışmalar ağız sözlüklerinin genişletilmesi açısından faydalı olacaktır. Ağız incelemeleri yapılırken sözcüğün metin üzerinden bağlamı incelenerek hem gerçek anlamı ortaya konulacak hem de aynı göstergenin farklı ağız bölgelerindeki anlam değişiklikleri tespit edilecektir. Standart dil ve ağızların karşılıklı alış verişi düşünüldüğünde bu tip metinlerde ağız kullanımının dilin gelişmesine katkı sağlayacağı açıktır. Metinlerde ağız kullanımının terimleşmeye ve sözlük dağarcığının zenginleşmesine faydalı olduğu düşünülmektedir. Türkiye Türkçesi ağızlarının her yönü ile tespit edilmesi ve ağız atlasının ortaya çıkarılmasında bu tip çalışmalara yer verilmesi gerekmektedir. Bu amaçla ağız araştırmalarına kaynak olacak eserler belirlenip elde edilen veriler belirli sınıflandırma ölçütleri ile incelenerek kullanılan ağızın hangi bölgeye ait olduğu ortaya çıkarılmalıdır. Taranan ve dokümantasyonu sağlanan veriler ait olduğu ağız grubunun her yönüyle incelenmesini sağlayacaktır. Edebi eserlerde standart dışı dil kullanımının daha geniş bir çerçevede araştırılması şüphesiz dil, edebiyat ve kültür incelemeleri açısından yararlı olacaktır. 


\section{KAYNAKÇA}

AKAR, Ali (2009a), “Ağ1z Sözlükleri: Yöntem ve Sorunlar -I-“ Turkish Studies, 4(4), 1-11.

AKAR, Ali (2009b), “Ağ1z Sözlükleri: Yöntem ve Sorunlar -II-“ Turkish Studies, 4(8), 216-224.

AKSOY, Ömer Asım (1988), Atasözleri ve Deyimler Sözlü̆̆̈̈ I-II, İstanbul: İnkılap Yayınevi.

AKSOY, Ömer Asım, vd. (2009), Bölge Ağızlarında Atasözleri Ve Deyimler I-II, Ankara: TDK Yayınları.

AYDIN, Mehmet. (2011), "Birkaç Örnek Çerçevesinde İç Göçlerin Ağızlara Etkisi", Turkish Studies, 6(1), 1894-1903.

AYDIN, Muhammet (2013). Bekir Yıldız'ın "Alman Ekmeği" Adlı Eserinde, Almanya'da Yaşayan Türk Vatandaşlarının Yaşadıkları Sosyal Ve Siyasal Sorunlar, Van: Yüzüncü Yıl Üniversitesi Sosyal Bilimler Enstitüsü (Yayımlanmamış Yüksek Lisans Tezi)

BASKAK, Sevgil (2008), Bekir Yıldız'ın Öykücülü̆ğ̈, Adana: Çukurova Üniversitesi Sosyal Bilimler Enstitüsü (Yayımlanmamış Yüksek Lisans Tezi)

BAYCANLAR, Sema (2007), Türk Edebiyatında 1951-1961 Yıllarında Edeb̂̂ Eleştiri, Adana: Çukurova Üniversitesi Sosyal Bilimler Enstitüsü (Yayımlanmamış Doktora Tezi)

BULUT, Serdar (2012), Anadolu Ağızlarında Kalıp Sözler Ve Kullanım Özellikleri. Ordu: Ordu Üniversitesi Sosyal Bilinler Enstitüsü ( Basılmamış Yüksek Lisans Tezi)

BURAN, A.hmet (2002), “Konuşma Dili Yazı Dili İlişskileri Ve Derleme Faaliyetleri”, Türkbilig, 4, 97-104.

BURAN, Ahmet (1996). Anadolu Ağızlarında İsim Çekim Ekleri. Ankara: TDK Yayınları.

DEMIR, Nurettin. (2009). "Edebi Metinlerde Ağız Kullanımı Hakkında Bir Ön Çalışma”, Bernt Brendemoen Armağanı http://s3.amazonaws.com/academia.edu.documents/40733038/berntarmagani.pdf Erişim tarihi: 20. 10. 2015

DEMİ, Nurettin (2010), “Türkçede Varyasyon Üzerine”, Ankara Üniversitesi Dil ve TarihCoğrafya Fakültesi Türkoloji Dergisi, 17(2), 93-106.

DEMİR, Nurettin. (2013), Ankara Örneğinde Ağızların Belgelenmesi, Ankara: TDK Yayınları.

DEMİRCİ, Kerim (2014), Türkoloji İçin Dilbilim, Ankara: Anı Yayıncılık.

DEVELIOĞLU, Ferit (1980), Türk Argosu İnceleme Ve Sözlük, İzmir: Aydın Kitabevi.

GÜNŞEN, Ahmet (2006), “Anadolu Ağızlarında Farklı Bir Gelecek Zaman Eki Ve Çekimi: -1c1/-ici; ucu/-ücü", Turkish Studies /Türkoloji Dergisi, 1(2), 65-66.

İMER, K.amile (1990), Dil Ve Toplum, İstanbul: Gündoğan Yayıncılık.

KARAHAN, Leyla (2011), Anadolu Ă̆ızlarının Sinıflandırılması, Ankara: TDK Yayınları.

KARASOY, Yakup (2016), “-ganda / -Anda Bir Zarf-Fiil Eki Midir?” Dil Araştırmaları, 19, 7-16.

KOMISYON (2009), Türkiye’de Halk Ağzından Derleme Sözlü̆̆̈̈, Ankara: TDK Yayınları.

KOMISYON (2012), Türkçe Sözlük, Ankara: TDK Yayınları.

KORKMAZ, Zeynep (2003), Türkiye Türkçesi Grameri, Ankara: TDK Yayınları.

KORKMAZ, Zeynep (2010), Gramer Terimleri Sözlüğü, Ankara: Anı Yayıncılık.

MASDAR, Funda (2012), “Orhan Kemal Uyarlamalarında Çukurova Gerçeğinin Yansimaları", Turkish Studies, 7(4), 2387-2400.

ÖZER, Abdulvahap (2007). Bekir Yıldız'ın Hikâye Ve Romanlarında Sosyal Meseleler, Konya: Selçuk Üniversitesi, Sosyal Bilimler Enstitüsü (Yayımlanmamış Yüksek Lisans Tezi)

ÖZER, Abdulvahap vd. (2013). “Bekir Yıldız'ın Türk Edebiyatındaki Yeri Ve “Kaçakçı Şahan” Adlı Hikâyesinin Tahlili", Dede Korkut Türk Dili ve Edebiyatı Araştırmaları Dergisi, 2(4),118-127.

DERLEME SÖZLÜĞÜ (Türkiye Türkçesi Ağızları Sözlüğü), TDK Online Sözlük http://www.tdk.gov.tr/index.php?option=com content\&view=article\&id=645 Erişim tarihi: 0307. 2017.

ŞENGÜL, Murat (2009). “Sosyal Farklılıklardan Kaynaklanan Dil Kullanımı Ve Türkçe Eğitimine Yönelik Bir Değerlendirme", Turkish Studies, 4(8), 2166-2180.

YILDIZ, Bekir (1975). Kaçakçı Şahan, İstanbul: Cem Yayınevi.

YILDIZ, Bekir (1977). Reşo A ̆̆a, İstanbul: Cem Yayınevi.

YILDIZ, Bekir (2006). Alman Ekmeği, İstanbul: İskele Yayıncılık.

YILDIZ, Bekir (2006). Yargılayan Zaman İçinde, İstanbul: İskele Yayıncılık.

ZÜLFIKAR, Hamza (2011), Terim Sorunları Ve Terim Yapma Yolları. Ankara: TDK Yayınları. 
Kaynak Kişiler:

$\begin{array}{llll}\text { Ad-Soyad } & \text { Yaş } & \text { Bölge } & \text { Meslek } \\ \text { Cihan ORUÇ } & 30 & \text { Kars } & \text { Araştırma Görevlisi } \\ \text { Emine Göztaş } & 51 & \text { Adana } & \text { Ev hanımı } \\ \text { Nuray Kaynak } & 63 & \text { Adana } & \text { Ev hanımı } \\ \text { Sedat Solgun } & 23 & \text { Urfa } & \text { Öğrenci } \\ \text { Şahin Taşgülük } & 22 & \text { Ardahan } & \text { Öğrenci }\end{array}$

